\title{
On the issue of growth and development within the context of tourism
}

\section{Ondřej Repík}

e-mail: ondrej.repik@econ.muni.cz

Faculty of Economics and Administration, Masaryk University, Brno, Czech Republic

Repík, O. (2014). On the issue of growth and development within the context of tourism. Czech Journal of Tourism, 3(2),

127-146. DOI: 10.1515/cjot-2014-0007.

\begin{abstract}
The question of growth and development is an issue much discussed by professionals as well as the wide public. These discussions are increasingly concerned with tourism, its significance for economic growth and development and its positive and negative consequences. The question of how tourism is to be coordinated in order to help achieve set priorities in the most effective way is related to this. The following text gives a summary of miscellaneous approaches to and views on this issue.
\end{abstract}

\section{Keywords}

growth, development, sustainability, tourism, regional development

JEL classification: O10, O40, R11 / Accepted: 17 July 2015 


\section{Introduction}

Tourism can be said to be one of the catalysts of the current global economy. Travelling is a modern estate with growing demand to which ever-growing and widening supply responds. During its development in advanced countries of the world travelling has transformed from a luxurious estate to an estate of popular consumption (Page \& Connell, 2009). This is related not only to the transformation of the entire society but also to technological advances that are behind these changes. Thus, tourism constitutes one of the fastest developing market environments. In most countries of the world tourism is at the same time a powerful economic branch with a significant share in GDP (Dwyer \& Forsyth, 2006). Besides this, it transforms the society, interferes with the environment and makes an impact on our close surroundings. All these connections related to tourism are the cause of why the phenomenon of tourism and its influence on economic and societal development are a popular subject of research (Page, 2007).

The gradual development of tourism and the change of its status within the society and economy go hand in hand with scientific and research activities in this sphere. Economists, geographers, sociologists, environmentalists and other specialists have been aware from the very beginning of the $20^{\text {th }}$ century that the phenomenon of travelling, getting to know other places and seeking ways to spend one's free time has been growing in significance (Becker, Hopfinger, \& Steinecke, 2007). The significance of tourism is growing as the society is becoming richer and more advanced. On the other hand, tourism is also becoming an important factor that influences the quality of life and makes the spiral of the further development of the society go round faster and faster (Ryan, 2003).

Within the context of the previous text, the goal of this article is to present authors' complex overview of the approaches to the issue of economic and societal growth and development related to the development of tourism. So far most authors have only focused on a certain sector of theoretical models. Therefore they have not fully revealed the mutual links between growth models and development models and their developmental sequence.

\section{The development of approaches to growth and development}

Probably the most complex view of the issue of growth and development within the context of tourism is presented by Sharpley and Telfer (2004), who are of the opinion that, thanks to its rapid and continuous growth related to a number of consequences for the economy, tourism is one of the most effective ways to support development. This fact is true for developing countries as well as for advanced ones, in which tourism has already become an important and integral part of development concepts. Moreover, in developing countries tourism is a signal of profound political and economic changes. Therefore tourism is generally perceived as a symbol of the western lifestyle and a source of progress and modernization. 
If tourism is to be considered a tool of development, first of all, it is necessary to define what the term 'development' represents. Various specialised sources present various concepts of development, which determines the roles that tourism plays in this process. Economic theory in general pays relatively great attention to the issue of development and growth. As in other areas, findings, ideas and practical experience are gradually sorted out and a series of theories and models concerning this issue have occurred here, too. Mostly these are general theories, which, however, can be related to the sphere of tourism; alternatively, some theories consider tourism such an important economic and societal aspect that they deal with it separately.

At the most general level, development is considered a process that makes the society to transfer from one point to another (Samuelson \& Nordhaus, 2007). Changes in the relations within the society take place, the society transforms, and new ideas, bonds and personal preferences are forged. At the same time the influence of human activity on nature changes and so does the human perception of the riches and uniqueness of the natural environment (Goeldner \& Ritchie, 2006). The concept of development may be interpreted at the global, national, regional or local level since the immediate surroundings of the population are changed as its consequence. However, development is most often linked with the modernization in the style of advanced western countries achieved through economic growth. In the view of Holman (2011), development takes place when the national economy grows, national production capacities increase, and, at the same time, the level of the growth of the outputs is faster than the level of the growth of population.

For instance, Sharpley and Telfer (2004) understand the term 'development' as a socio-economic change and progress and the growth of qualitative indicators, the growing revenue per capita, decline in poverty, greater social justice, modernization in the form of social changes, a higher employment rate, better access to medical care, or better life with a larger portfolio of options for self-fulfilment. Nonetheless, development has many dimensions. It is studied from the perspective of many fields, which, as a result, prevents putting together a universal definition of it.

On the other hand, Stabler, Papatheodorou, and Sinclair (2010) understand economic growth as the increase in the volumes of goods and services that the economy produces within a certain unit of time. If available sources are not fully and efficiently used, the real growth can still be achieved even though the total production capacities of the economy are not growing. However, the potential growth means the pushing of the boundaries of production options up. The cause may be technological advances, the cultivation of human resources or improved infrastructure (Samuelson \& Nordhaus, 2007). In this context, the potential growth is also understood by other authors as the so-called 'economic development'.

As late as the half of the $20^{\text {th }}$ century, the terms 'development' and 'economic development' (or 'economic growth') were understood as synonyms. This is because economic forces played such a significant role that they had become the prerequisite of development. In the fifties and the sixties of the $20^{\text {th }}$ century, the idea that the journey from the backward to the advanced is composed of various economic cycles begins to spread. 
Therefore in this period development begins to be defined through economic indicators, such as GDP or GDP per capita, or through criteria that describe structural changes in the economy (Holman, 2011).

However, at the end of the sixties, it becomes clear that economic growth fails in solving social and political problems. Despite the fact that the national economies of the time fulfilled their growth objectives, the standard of living of the majority had not changed (Holman, 2005). The term 'development' begins to be understood in a wider context that includes the questions related to education, health care or housing. During the seventies the understanding of development progressively frees itself of economic aspects. The question of development becomes more involved with poverty in the society, unemployment and the self-sufficiency of the individual.

Thus, the concept of economic development has moved, within half a century, from the economic growth to the concept including far-reaching, permanent and positive changes within the framework of human existence. Some authors speak of the concept of 'happy life', which includes the fulfilment of social, cultural, political, environmental and economic goals (Sharpley \&Telfer, 2004).

For example, Cooper, Fletcher, Fyall, Gilbert, and Wanhill (2008) state that as far as tourism is concerned, its contribution to development shall be interpreted within a wider context. In fact, many experts present tourism as a panacea for structural problems and backwardness. Its socioeconomic consequences are assessed separately from the surrounding world and the remaining sectors of the economy. However, it is unrealistic and short-sighted to take one sector (e.g. tourism) and consider it the solution to all problems that developing countries and structurally handicapped regions have to face. On the other hand, it is logical that the topics of 'tourism' and 'development' are often put together in the national, global and local context (Theobald, 1998). Hall and Lew (2009) emphasise that tourism is a sector highly promoting growth and a cross section sphere that transfers positive signals into the entire economy and society.

The following scheme presents the model of Sharpley and Telfer (2004), which demonstrates mutual links between tourism and its surrounding socio-cultural, political and economic environment. It depicts the various consequences of tourism in this environment, which also constitute some of the factors of development. The model shows these following points: It is possible to study individual aspects of tourism, its specific consequences and external factors that influence the nature of the development of tourism. But still each such element is only a part of the dynamic system of development in which all these elements influence one another.

Cooper, Fletcher, Gilbert, Fyall, and Wanhill (2008) state that development is a never-ending process that takes place in the ever-changing environment. Especially the holders of the tourism policy who create concepts of sustainable development shall be aware of this fact. Therefore the set objectives and tools used shall be in harmony with current and future trends and the changing environment (Hall \& Jenkins, 1995). At the same time the development of tourism can never be optimal unless it is based on a certain consensus and cooperation among the individual stakeholders involved in tourism (Goulet, 1989). The fact is that the private sector tends to be short-sighted and tends to 
Figure $1 \mathrm{~A}$ model depicting the relationship between tourism and development

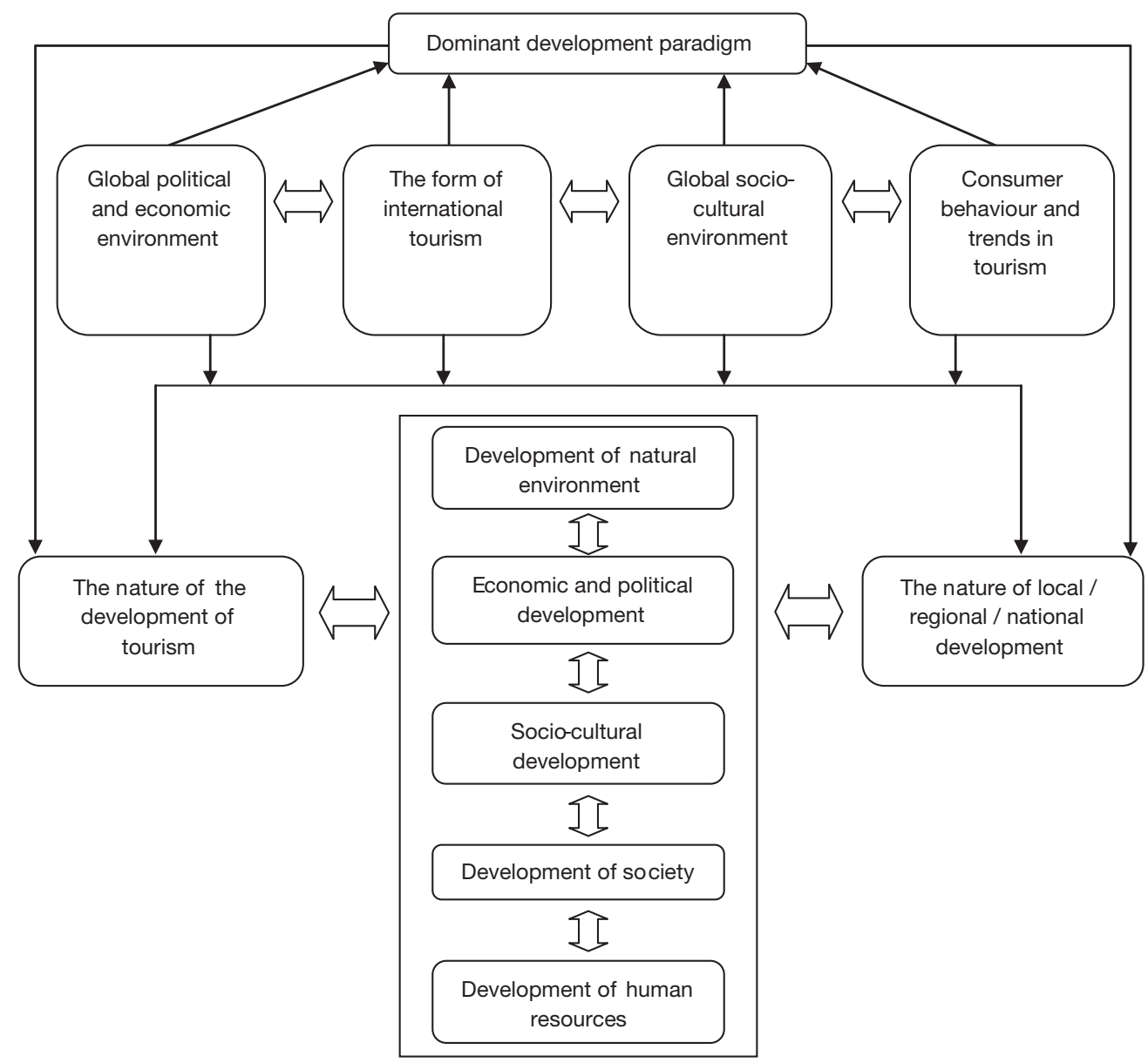

Source: Sharpley and Telfer (2004)

focus on short-term assets and goals. On the other hand, the public sector should take a long-term perspective on individual sectors backed up with a concept and considering a wider context (Veal, 2002). Goldner and Ritchie (2006) list the most important developmental objectives in tourism:

- securing conditions for the improvement of the standard of living through the economic assets of tourism;

- the development of infrastructure and recreational facilities for residents and nonresidents;

- the development of tourism in regions and destinations in a way that is in accordance with the nature and specifics of the given area; 
- the tourism development program in a given area shall be in accordance with the cultural, social and economic philosophy of the local government and local population;

- the satisfaction of demand shall be maximised.

If tourism is to be a part of the all-national development concept, it has to be managed and developed on the basis of a well-grounded strategy (Inskeep, 1994; Murphy \& Murphy, 2004). Within this, the holders of the tourism policy shall take into account the coordination of industries related to tourism and base their assumptions on the supply and demand in tourism (Elliott, 1997). The planning process for the development of tourism is influenced by many stakeholders and interest groups the objectives of which may be in conflict (Hall, 2008).

\section{Tourism and development theory}

Tourism is a part of many theories of development, being presented as a more or less significant tool to secure development and all its attributes. Individual theories continuously study the potential of tourism to initiate development and the ability of individual stakeholders to identify and quantify all its contributions and costs for the economy and society.

For instance, the following authors deal with tourism within their development theories: Hall and Page (2006); Goeldner and Ritchie (2006); Cooper, Fletcher, Fyall, Gilbert, and Wanhill (2008); Sharpley and Telfer (2004); Stabler, Papatheodorou, and Sinclair (2010); Tribe (2012) and many others. It is clear from available resources that general theories of development and theories of the development of tourism have been developing since the Second World War in a similar way and with a similar timescale. However, the first research studies concerning tourism occur as early as the thirties of the $20^{\text {th }}$ century. They were spurred by the development of mass tourism. The proponents of post-war research were especially institutions such as World Bank, UN or OECD. In the sixties tourism was understood as one of the significant tools of development (Cooper, Fletcher, Fyall, Gilbert, \& Wanhill, 2008). Tourism functioned within the 'modernization theory' of the time as the creator of employment and the source of revenues from abroad, and its powerful multiplication effects and their influence on the local economy were highlighted (Sharpley \& Telfer, 2004).

However, in the course of time, many experts begin to dispute the assets of tourism. They emphasize that in reality its multiplication effects are far lower than they have been calculated up to then. At the same time opinions that tourism need not always be the suitable tool for development begin to occur (Stabler, Papatheodorou, \& Sinclair, 2010). Critical views of this kind can be identified, for instance, on the part of the proponents of the so-called 'dependency theory'. In the 80 s and 90 s neoliberal economy enters the stage, which, as far as tourism is concerned, focuses on international markets and considers tourism an invisible export industry of the services sector. In the following periods 
tourism is mostly studied from the viewpoint of the sustainability concept, which becomes a part of 'theories of alternative development'. Here the subject of interest is new and alternative types of tourism, such as ecotourism. These approaches are studied in depth by, among others, Goeldner and Ritchie (2006) or Tribe (2012).

The following table sums up the basic concepts of four main theoretical views concerning the development issue after the Second World War. The following text studies the individual views in closer detail.

Table 1 Main theoretical approaches to the development issue

\begin{tabular}{|c|c|c|c|}
\hline Period & $\begin{array}{l}\text { Development } \\
\text { paradigms }\end{array}$ & $\begin{array}{l}\text { Selected theoretical } \\
\text { approaches or models }\end{array}$ & Key strategies/concepts/topic \\
\hline \multirow[t]{2}{*}{$\begin{array}{l}50 \text { s and } 60 \text { s } \\
\text { of } 20^{\text {th }} \text { century }\end{array}$} & \multirow[t]{2}{*}{$\begin{array}{l}\text { Modernization } \\
\text { theory }\end{array}$} & Division into stages & $\begin{array}{l}\text { all societies undergo the same developmental } \\
\text { stages that has already taken place in western } \\
\text { countries }\end{array}$ \\
\hline & & Diffusion & $\begin{array}{l}\text { spreading of growth impulses from advanced } \\
\text { regions; growth poles; state interventions; } \\
\text { development of regional economy }\end{array}$ \\
\hline \multirow[t]{3}{*}{$\begin{array}{l}50 \text { s and } 60 \text { s } \\
\text { of } 20^{\text {th }} \text { century }\end{array}$} & \multirow[t]{3}{*}{$\begin{array}{l}\text { Dependency } \\
\text { theory }\end{array}$} & Neocolonialism & $\begin{array}{l}\text { lagging behind caused by the exploitation of } \\
\text { sources by advanced countries; influence of } \\
\text { the culture of western countries }\end{array}$ \\
\hline & & Dualism & $\begin{array}{l}\text { poverty is a function of global economic } \\
\text { growth; the rich and the poor - among } \\
\text { countries and within countries; regional } \\
\text { disparities }\end{array}$ \\
\hline & & Structuralism & $\begin{array}{l}\text { local markets; substitutes of imported } \\
\text { goods; social reforms; protectionism; state } \\
\text { interventions }\end{array}$ \\
\hline \multirow{3}{*}{$\begin{array}{l}\text { Second half } \\
\text { of } 70 \text { s and } \\
\text { the } 80 \text { s } \\
\text { of } 20^{\text {th }} \text { century }\end{array}$} & \multirow[t]{3}{*}{$\begin{array}{l}\text { Economic } \\
\text { neoliberalism }\end{array}$} & Free market & $\begin{array}{l}\text { macroeconomy of the supply part; principle of } \\
\text { free market competition; privatization }\end{array}$ \\
\hline & & Structural changes & $\begin{array}{l}\text { focus on market forces and competitive } \\
\text { exports }\end{array}$ \\
\hline & & One world & $\begin{array}{l}\text { global introduction of a new financial system; } \\
\text { decisions on production issues are made in } \\
\text { the international scale }\end{array}$ \\
\hline \multirow[t]{4}{*}{$\begin{array}{l}70 \text { s and } 80 \text { s } \\
\text { of } 20^{\text {th }} \text { century }\end{array}$} & \multirow[t]{4}{*}{$\begin{array}{l}\text { Alternative } \\
\text { development }\end{array}$} & Basic needs & $\begin{array}{l}\text { priorities are food, housing, water, health and } \\
\text { education }\end{array}$ \\
\hline & & Local activities & $\begin{array}{l}\text { development oriented towards people; powers } \\
\text { to make decision at local level; strengthening } \\
\text { of local activities; non-profit sector }\end{array}$ \\
\hline & & Gender & $\begin{array}{l}\text { the status of women within development; } \\
\text { relations between sexes; stronger position of } \\
\text { women }\end{array}$ \\
\hline & & $\begin{array}{l}\text { Sustainable } \\
\text { development }\end{array}$ & $\begin{array}{l}\text { management of natural environment; meeting } \\
\text { the needs of the current generation without } \\
\text { discriminating the needs of future generations }\end{array}$ \\
\hline
\end{tabular}

Source: Sharpley and Telfer (2004), adjusted by the author 


\section{Modernization theory}

Modernization is defined as socio-economic development that follows the evolution curve from the traditional society to the modern society in the form that exists in North America or Europe. The fundamental feature is the shift from agriculture towards industry, from the rural to the urban, while the financial sector plays the crucial role. The influence of the family declines and institutions are more differentiated. The modernization theory springs from various views the holders of which belong to the opposition of Marxists. The original roots of modernization can be traced to the growth of economic theory, which is based on Keynes models. The modernization concept also includes the theories and strategies of regional development, which study, among other things, the transfer and diffusion of growth impulses in a geographic area.

The proponents of modernization are criticized for the excessive level of abstraction. For instance, the proponents of the Dependency Theory have it that modernization is an ideology the sole point of which is to justify the western involvement and dominance in the developing world (Sharpley \& Telfer, 2004).

Modernization was one of the basic theoretical approaches in developing countries. In this context, tourism is considered a developmental tool that increases employment rate, generates revenues from abroad, increases GDP, brings in developmental capital, and is a tool for the transfer of technologies and a tool for regional development. At the same time tourism serves to support the modern lifestyle with western values and is considered an integral part of the modern society. The role of the state is to create basic conditions for its growth (Goeldner \& Ritchie, 2006).

\section{Dependency theory}

The Dependency Theory is one of the best known neo-Marxist theories of development. Its proponents have it that developing countries have external and internal political, institutional and economic structures that keep them in constant dependency on advanced countries. These international models of dependency have attracted many supporters, especially in developing countries. This is one of the reasons why the dependency theory is associated with the study of causes why a given economy lags behind others, rather than being a theory studying the factors and consequences of development. Some authors study and develop the dependency theory within the framework of regional development. These are of the opinion that inter-regional disparities are the consequence of economic development (Sharpley \& Telfer, 2004).

For instance, the so-called Dualistic model is based on the division of the society into the rich and the poor, which exists in advanced countries as well as in developing countries. Poor regions are indispensable for the rich ones because they supply them with workforce. The dualistic model states that these problems are of chronic nature and the scissors between the rich and the poor keep opening (Desai \& Potter, 2002). On the other hand, structuralism crates the model of three economic zones: the core, the semi-periphery and the periphery. Within this model backwardness manifests itself at the 
moment when peripheries begin to cooperate and trade with advanced countries and integrate their economies into the international system of trade (Blažek \& Uhlír, 2002).

The dependency theory is most often criticized for its excessive generality, pessimism, rhetoricalness and for giving higher priority to the external developmental factors than to the internal ones. As a result, the majority of partial theories are based on a significant simplification of reality. The resulting models either become downright wrong or are too general and simplified to be used to deal with the majority of practical problems. Therefore the proponents of this theory are only rarely able to formulate any concrete and practical recommendations.

Cooper, Fletcher, Fyall, Gilbert, and Wanhill (2008) state that in the dependency theory tourism plays such an important role that its proponents have concern about the excessive dependency of a given economy on tourism and foreign suppliers related to it (tour operators, or transport companies). The significance of tourism is obvious within this theory. However, in an economy it can play the role of the stimulant or the deterrent of development.

\section{Economic neoliberalism}

Within the specialised literature on tourism, neoliberalism is dedicated much less space than the two preceding theoretical concepts. However, one of the aspects of neoliberalism is that it emphasises the role of competitive export products and tourism is an industry in the services sector with a high export potential. Another aspect of neoliberalism is the creation of supportive financial tools (e.g. SALP - Structural Adjustment Lending Programmes), while similar programs also occur in tourism. For instance, as far as tourism is concerned, the European Union globally supports the development and renovation of infrastructure, the cultivation of human resources, the creation of products and the marketing of tourism, the protection of the cultural and historical heritage, and expends means to support small and medium-sized firms active in tourism (Repík, 2013).

The advance of neoliberalism gives tourism much more significance in terms of economic activity, which generates revenues from abroad, lowers the unemployment rate, or helps to solve structural problems. In developing countries tourism can be a new impulse for the local economy. It is often the only industry in the developing country that has good prospects for future and brings an immediate effect.

Within the neoliberalism theory the state plays a much less significant role than in other theories. However, its role is still very important (Holman, 2005). Tourism is not an exception since governmental decisions may significantly influence investments in tourism, the selection of the target destination and the consumer behaviour in the destination itself. The state creates conditions for the developmental activities of the private sector. 


\section{Alternative theories of development}

Alternative theories of development are pragmatic, broadly conceived views that are largely based on the critical assessment of the previous models. Their economic models focus on the man and the environment in which he lives. Their rise in the 70s was initiated by international non-profit organisations seeking alternative approaches focused on man. The non-profit sector has become the main proponent of these approaches, thus, significantly increasing its influence on the local and community development. A number of non-profit organisations does fieldwork and are able to create innovative solutions to problems at the local level that are often more effective than standardized approaches advocated by the state (Sharpley \& Telfer, 2004).

Alternative theories of development include the concept of sustainable development the rise of which is related to the idea that the environment is not indestructible and is only available in a limited extent on the planet (Tribe, 2012). Individual authors interpret sustainable development differently. Most often it is assumed that sustainable development is such a development that satisfies the needs of the current generation without discriminating future generations (Wall \& Mathieson, 2006). Unlike with the previous approaches, the ecological aspect becomes, at last, a part of the economic system.

On the global scale the opponents of alternative theories are as fragmented as the theory itself. The subject of criticism is mostly the fact that if applied, the theory may, in the long run, slow down the economic growth and lead to more powerful supervision from the state. Many authors consider the principle of sustainable development vague and ambiguous; it is often the case that it is not clear what is to be sustained, how, at what level, for whom and who is to decide on all this.

Alternative theories of development have attracted countless supporters, even in respect of tourism. These focus on a number of topical issues, such as the development of domestic tourism, the support of local entrepreneurs, the strengthening of the position of local stakeholders in the management process, the role of women in tourism and sustainable tourism. Sustainable development is one of the most discussed concepts in tourism. Relatively high attention is also dedicated to business entities and their structure. Some authors consider domestic tourism a better generator of local revenues than foreign tourism since it is more dependent on local resources. Also ecotourism, one of the fastest growing forms of tourism at present (Goeldner \& Ritchie, 2006) also perfectly fits the concept of alternative theories of development.

\section{The concept of sustainable development (as one of alternative theories of development)}

Sustainable tourism is based on the principle that population, in its consumption and production activities, shall respect future generations since people consume limited resources. However, Cooper, Fletcher, Gilbert, Fyall, and Wanhill (2008) are of the opinion that the term 'sustainable tourism' has not always been sufficiently explicated in specialised literature and so its interpretation may be confusing. They state that this concept has 
sometimes been confused with the concept of the economic growth and the necessity of its sustainability has therefore been emphasised. However, in reality development shall always be sustainable; otherwise, it cannot be considered as development. That is to say that the basic prerequisite of development is the fact that it takes into account environmental and socio-cultural aspects that make them sustainable. Some other publications mention the so-called 'self-sustainable' growth. Nonetheless, in this case it is necessary to bear in mind that if one assumes that resources are limited, the growth is possible only as a result of technological progress and innovations.

Goeldner and Ritchie (2006) state that the concept of sustainable development is a part of theories of economic development (growth), as well as theories of development as such. Its popularity is growing since it is based on the principle of maintaining the standard of living as it is at the present time. The basic idea lies in the knowledge that mankind can no longer use the global environment in the same extent as it used to in the past. Despite the fact that the question of sustainability is more urgent in other industries (mining, mechanical engineering, or metallurgy), tourism earns its place in the centre of attention because of its role in the society and economy. The subject matter within the concept of sustainable development is its contribution to the prospects of happy life on this planet in the long run.

Many authors of specialised literature deal with the issue of sustainable development in tourism. Some of them study the very essence of sustainability and the adequacy of development. They ask themselves questions such as the following ones: For whom shall development be adequate? Who will assess its adequacy (or in other words: Who will determine the level of sustainability)? People perceive adequacy differently. The very term 'sustainable development' has adopted many forms in the specialised literature and there is no generally accepted definition for it. Moreover, nobody has put together a scale of indicators to determine what sustainable development is and when its principle has been violated. In general, one can say that the professional public has agreed mainly on the fact that the development of tourism cannot be planned and evaluated separately from everything else. Tourism is influenced by a number of processes and activities and functions in a certain environment that forms it (Mowforth \& Munt, 2009).

If tourism is to be an integral part of local economy and society, it has to be developed in an adequate extent, the types of tourism shall be suitable, it has to be sustainable, its resources has to be used with forethought, suitable conditions have to be created for its development, the local community has to be engaged in the planning and decision making process (Wahab \& Pigram, 1997). Many authors have it that as far as the sustainable development of tourism is concerned, the key aspect is how it is perceived by the local community. The development of tourism shall be, in the short run and in the long run, in accordance with the needs of the local population, which will result in the improving quality of their standard of living (Blair, 1995). At the same time it is necessary to consider the protection of the environment and of cultural values (Sharpley \& Telfer, 2004). 


\section{Tourism and the growth theory}

Economic development is mostly linked to structural changes in economy when one identifies the transfer from the primary sector to the secondary sector and subsequently, to the services sector. One of the manifestations of development is the continuous improving of the standard of living across the entire population. Thus, the economic development is usually linked with the economic growth. However, the economic growth need not necessarily result in the economic development (Stabler, Papatheodorou, \& Sinclair, 2010). The basic difference between the development and the growth is that the growth is always understood purely in the economic dimension, while the development includes environmental, social, cultural and other issues. The economic growth is a daily topic for all communication media since the general public perceives this term as the clear tool to assess the current condition of the economy and the ways in which it will develop in future.

As far as tourism is concerned, the issue of economic growth shall be interpreted in more complex terms than in the case of a production process. On the other hand, the qualitative growth in this case is also established in the situations when the units of production factors are sufficiently involved. Building a new winter recreational centre sufficiently involves the units of capital and labour and it will result in the increase of economic quantities. The development of basic and ancillary infrastructure can be, figuratively speaking, considered the qualitative resources of growth. From a different viewpoint, the role of the qualitative resources of growth in current tourism is becoming more and more significant. The amount of information, the way of its presenting and its composing into a concrete packet (product) are the agents of modern tourism and determine the direction of the economic growth related to them. Thus, the marketing of tourism is a set of qualitative resources of the current economic growth.

According to Capello and Nijkamp (2009), there are three basic approaches to the issue of economic growth within the framework of economic theory. The following table sums up their basic characteristics and the form of tourism. It should be said that the classical model and the Keynesian model are borderline and theoretical models. Most authors use them to present certain partial phenomena in tourism that can be explicated better on their basis. However, these two models are insufficient for the exploration of more complicated practical problems in tourism.

The aforementioned basic models have been adopted in theory to create various partial interesting approaches. Keller and Bieger (2007) devoted part of their research to productivity in tourism. Cooper, Fletcher, Gilbert, Fyall, and Wanhill (2008) mention, for example, Marx's historical approach or Rostow's identification of the stage of the economic growth.

In the framework of Marx's development theory, tourism has a clear role of the driving force for economic, social and political changes. Tourism makes it possible to accelerate the process of changes thanks to its product-based nature that allows for fast development and assists the process of transformation from capitalist over to socialism and to communism. However, in tourism there are activities that are linked to high 
Table 2 Basic theoretical models of the economic growth in tourism

\begin{tabular}{|c|c|}
\hline $\begin{array}{l}\text { Growth } \\
\text { models }\end{array}$ & Characteristics of individual models \\
\hline $\begin{array}{l}\text { Classical } \\
\text { models }\end{array}$ & $\begin{array}{l}\text { The principle of non-intervention is the basic component of classical } \\
\text { models. Here the public sector acts as an agent that 'only' creates the } \\
\text { basic boundaries for the functioning and the future form of tourism. At the } \\
\text { same time these are purely theoretical models based on many assumptions. } \\
\text { Most contemporary authors understand this model as one of borderline } \\
\text { approaches. According to Cooper, Fletcher, Gilbert, Fyall, and Wanhill (2008), } \\
\text { tourism, as well as other industries, has no privileged position in classical } \\
\text { models. The decisive aspect for its further growth is the limits given by the } \\
\text { limited land resources. }\end{array}$ \\
\hline $\begin{array}{l}\text { Neoclassical } \\
\text { model }\end{array}$ & $\begin{array}{l}\text { With neoclassical models the process of the economic growth is related to } \\
\text { the production efficiency in tourism. The role of the public sector is stronger, } \\
\text { often the epithet, 'coordinating' is used here. The priority is to create } \\
\text { a maximally effective and favourable environment for the further growth of } \\
\text { tourism (in this case, this mainly means the qualitative growth). However, the } \\
\text { interventions in the market mechanism are minimal. }\end{array}$ \\
\hline $\begin{array}{l}\text { Keynesian } \\
\text { models }\end{array}$ & $\begin{array}{l}\text { Keynesian models deal with the economic growth, mainly from the short-term } \\
\text { viewpoint. In them the main goal is to fully use the resources in tourism that } \\
\text { have not been sufficiently used so far. Moheb (1976) mentions, that these } \\
\text { models are demand-oriented. The models create an opposition to the view of } \\
\text { the classical school of economics. The public sector is a powerful stakeholder } \\
\text { in tourism that corrects market imperfections and stimulates tourism to further } \\
\text { growth (here it mainly means the qualitative growth based on the maximising } \\
\text { of the use of resources). }\end{array}$ \\
\hline $\begin{array}{l}\text { Theories of } \\
\text { endogenous } \\
\text { growth }\end{array}$ & $\begin{array}{l}\text { The theory of the endogenous growth examines the economic growth from } \\
\text { the viewpoint of competitiveness and long-term performance. The basic } \\
\text { prerequisite for the growth is the continuous introduction of innovations in } \\
\text { tourism. This is a model that can be used to explicate many phenomena } \\
\text { that occur in the practice of tourism. The same is true for other sectors, } \\
\text { innovations play an irreplaceable role for the further growth of tourism } \\
\text { (Nordin, 2003). }\end{array}$ \\
\hline
\end{tabular}

Source: the author

economies of scale (natural monopolies - e.g. airlines) that hinder the transformation from capitalism to egalitarian systems.

Tourism has a strong position in the society and in economics also in Rostow's concept. Here the basic attribute of the development of tourism is the development of transport and infrastructure accompanied with the influx of capital, which are strong impulses for the economic growth in themselves. Tourism is considered one of the most important tools for the development of backward and developing countries (Fayissa, Nsiah, \& Tadasse, 2008). 


\section{Tourism and regional development}

The issue of growth and development of tourism shall also be considered from the regional (or local) viewpoint. Governments and development organisations all over the world consider tourism a suitable tool within the framework of regional development and politics. While the goals of regional development may vary, the main concern is to even out or narrow the gap in life chances, employment opportunities and real income of the citizens regardless of which region of the country they come from (Sharpley \& Telfer, 2015). A number of specialists and politicians view tourism as a way to level economic inequality among regions. One of the most significant properties that have been a key to its success in regional politics is its ability to promote its assets in the surrounding regions. Moreover, Lordkipanidze, Brezet, and Backman (2004) claim, that development of small-scale tourism entrepreneurship can contribute to the sustainable regional development by strengthening the local culture and identity, by diversifying rural tourism activities and by keeping the rural population in the region as well as by minimizing environmental impacts due to the small-scale character of rural tourism enterprises.

Already Christaller (1963) claimed within his core-periphery model that tourism may be a tool to achieve the economic development in the peripheral regions that are visited by rich tourists from the metropolis (the core). Examples of the peripheral regions visited by people from the metropolis can be found among seaside, rural or alpine regions. Since these regions are often below the level of the mean values of socioeconomic indicators at the national level, tourism may adopt an important role in redistributing the riches from wealthy metropolitan areas to the poorer periphery.

Christaller was one of the first authors who studied and researched tourism and its impacts from the regional point of view. Since then there have been many other authors who have researched the impacts of tourism in the development of individual regions. Most of the authors chose regions of mass tourism where they were able to present how tourism could transform the region. For example, Seckelmann (2002) studied how domestic tourism had stimulated the development of regions in Turkey. Loukissas (1982) carried out a comparative analysis in case of impacts on Greek islands. The case of the Czech Republic is researched by many authors and scientists. Recently, those have been Antoušková (2008) or Tluchoř (2012) who dedicated their research to the topic of regional development and the role of tourism.

Sharma (2004) researched the influence of tourism on cities' development and development of countryside. Brenner and Aguilar (2002) investigated the influence of luxury tourism in Mexico on regional economic development. Other authors studied the competitiveness of regions in tourism, the evolution of new products as tools to raise the competitiveness and also the role of marketing and management in modern tourism. Giaoutzi and Nijkamp (2006) researched connection between tourism, ICT, innovations and regional development. Skokan (2004) studied the field of clusters in tourism and their role in regional development. Then, for example, Butler (1980) developed the Tourism Area Cycle of Evolution, which draws on the product life cycle. Shaw, Williams, and Cooper (1990) researched the role of entrepreneurial activity in tourism and its 
development. Tosun, Timothy, and Özturk (2003) examined the impacts of intensive coastal tourism growth on the development of rural regions.

As it has been mentioned before, although tourism has the potential to generate the growth and development, it can also deepen inequality in a given area. For example, Malecki (1997) noted a series of negative factors which can prevent tourism from being an effective tool for regional development. At the top of Britton's (1982) enclave model of tourism development there are the head offices of global and national tourism firms, which control the industry, and funds generated through tourism are leaked out of the tourist region back to the metropolitan countries.

Tourism is a part of many theoretical approaches that examine economic development in regions. Thanks to its indisputable influence on the development of regions, tourism is attracting the focus of the attention of national and regional governments (Shaw \& Williams, 2002). In many countries new or completely renovated tourist centres were established (e.g. Cancún) that are to fulfil the role of growth poles. They are often located in backward parts of the country that, on the other hand, have the potential for tourism. The infrastructure and superstructure in these centres are built up on a massive scale and entrepreneurial activities are significantly subsidized, at least at the beginning. It is a typical feature of these centres that they promote a number of their positive effects on the entire region and the remaining parts of the country. On the other hand, it is typical of the globalised world of the present times that in response to the development of tourism, the destination becomes excessively dependent on a certain commodity or service provided by a supranational supplier (Sharpley \& Telfer, 2015).

\section{Results}

As it has been mentioned above, the issue of growth and development is the topic for many authors. However, most of them focus on a certain sector of the issue and do not provide a complex overview of theoretical approaches. It also applies that the speed of the development of tourism is matched by the development of partial theoretical approaches related to it.

Within the framework of growth models theoreticians agree that tourism is one of the driving forces of the globalised economy of today and a significant factor of the economic growth (Balaguer \& Cantavella-Jordá, 2002). Tourism underwent a skyrocketing expansion in the second half of the twentieth century and as such it became one of the initiators of the economic growth. The authors have focused purely on the economic effects of tourism in their papers. The environmental and socio-cultural aspects of tourism have not been attended to. Thus, their theories present the indispensable viewpoint of the economists on this issue. However, essentially, they face the problem of not being able to calculate the real expended resources related to the execution of activities in tourism. For this reason, specialised literature dedicates little space to the link between tourism and the economic growth.

On the other hand, the phrase 'economic and social development' in relation to the development of tourism is used relatively often in specialised literature. Nonetheless, 
Table 3 Tourism and development theory

\begin{tabular}{|c|c|c|c|c|}
\hline $\begin{array}{l}\text { Components of } \\
\text { development }\end{array}$ & $\begin{array}{l}\text { Modernization } \\
\text { theory }\end{array}$ & $\begin{array}{l}\text { Dependency } \\
\text { theory }\end{array}$ & $\begin{array}{l}\text { Economic } \\
\text { neoliberalism }\end{array}$ & $\begin{array}{l}\text { Alternative } \\
\text { development }\end{array}$ \\
\hline \multicolumn{5}{|c|}{ A) the level and supervision of development } \\
\hline focus & economic & economic & economic & sustainability \\
\hline level of development & great & great / small & great & small \\
\hline rate of development & fast & fast & fast & gradual \\
\hline economic dimension & $\begin{array}{l}\text { from the rich to } \\
\text { the poor }\end{array}$ & local owners & credit programs & local owners \\
\hline planning & $\begin{array}{l}\text { from top } \\
\text { to bottom }\end{array}$ & $\begin{array}{l}\text { from top to } \\
\text { bottom }\end{array}$ & $\begin{array}{l}\text { from top to } \\
\text { bottom }\end{array}$ & $\begin{array}{l}\text { from bottom } \\
\text { to top }\end{array}$ \\
\hline local level & limited & strong & limited & strong \\
\hline ownership & foreign & local & foreign & local \\
\hline supervision of industry & external & internal & external & internal \\
\hline role of the state & great / small & great & small & great / small \\
\hline origin of the management & foreign & domestic & foreign & domestic \\
\hline type of accommodation & great resorts & $\operatorname{mix}$ & great resorts & $\operatorname{mix}$ \\
\hline local dimension & concentrated & miscellaneous & concentrated & miscellaneous \\
\hline type of tourists & mass tourist & $\operatorname{mix}$ & mass tourist & special interest \\
\hline marketing goal & $\begin{array}{l}\text { packets of } \\
\text { services }\end{array}$ & $\operatorname{mix}$ & $\begin{array}{l}\text { packets of } \\
\text { services }\end{array}$ & independent \\
\hline type of employment & formal & no / formal & formal & no / formal \\
\hline infrastructure level & high & high / low & high & low \\
\hline capital inputs & high & high / low & high & Iow \\
\hline transfer of technologies & high & $\operatorname{mix}$ & high & $\operatorname{mix}$ \\
\hline \multicolumn{5}{|c|}{ B) environmental and social context } \\
\hline use of resources & high & high / low & high & low \\
\hline $\begin{array}{l}\text { protection of the } \\
\text { environment }\end{array}$ & low & $\operatorname{mix}$ & low & high \\
\hline internal integration & low & high & low & high \\
\hline interbranch links & low & high & Iow & high \\
\hline cultural awareness & exploitative & protectionist & exploitative & protectionist \\
\hline development of institutions & low & high & low & high \\
\hline feeling of local belonging & low & high & low & high \\
\hline adaptive capacity & low & low & low & low \\
\hline
\end{tabular}

Source: Sharpley and Telfer (2004), adjusted by the author 
these approaches, too, have undergone various developmental stages - from the modernization theory emphasizing the economic growth to alternative theories (or theories of sustainable development). Thus, the discussion about the development of tourism has moved from the support of the economic effects of tourism to the economic development and all the way to the negatives related to the development of tourism. The negatives are mainly grounded in non-economic spheres, such as the negative effects on the environment in the destination (the natural environment, the social and cultural environment), or the negative specifics of the development of tourism in less advanced countries (Eadington, 1992). With many authors the discussion concerning the development of tourism is excessively simplified, as they ignore a number of circumstances. The following table sums up the basic features of the four development theories mentioned above. Those characteristics have been selected on the basis of their relation to tourism.

\section{Conclusion}

It is obvious from the available literature that various authors treat the term 'development' differently. Some identify it with the economic development; others see behind it, for instance, structural changes, capitalism or socialism, self-fulfilment and self-sufficiency (individual, national, regional or cultural). The concept of development was studied for the first time after the World War Two when it was perceived as the economic growth. The social and cultural aspects of development were only examined to the extent to which they facilitate the growth. Later, a broader perspective was adopted towards the issue of development that included social, moral, ethical and environmental questions. To put it simply, the issue of the development of human society and of its overall improvement was examined. On the other hand, even the contemporary authors differ in their approaches to the issue of development. Moreover, individual authors focus only on the selected segments of this issue.

The specialised literature dealing with the issue of growth and development in relation to tourism can principally be divided into three basic groups. The first group is made up of the sources focusing on the current influence of tourism on the economy. They examine the status of tourism, its links to other economic activities and what comes under the issue of tourism in general.

Another group of authors deals with the aspects of tourism influencing the society as a whole. Again, they put the influence on the economy in the first place. However, besides the economic aspect, they also pay attention to the effects on the social, cultural and natural environment. For these authors tourism is not merely an economic phenomenon but also becomes a crucial factor that determines the quality of human life and a factor forming the environment in which the society exists.

The third group of authors tries to delve into the issue as deep as possible and they examine the development of the influence of tourism on the society and economy itself. It is with these authors where general growth and development theories are adjusted to 
the issue of tourism. One of the crucial points of their understanding is, for instance, the fact that the level of the influence of tourism on the society and economy is significantly predetermined by the level to which a given community has advanced. The more advanced the community is, the more significant the status of tourism and the stronger its influence on further societal and economic development.

Generally speaking, tourism is viewed in specialised literature as a very fast growing sector that influences a number of other sectors of the economy. It is this very nature of its cutting across various industries, which makes its study from the viewpoint of growth and development very important. This is to say that from the viewpoint of the societal development, tourism is an element that significantly cultivates the quality of human life. On the other hand, it brings about considerable negative effects for the society, too.

\section{Acknowledgment}

This article was supported by the specific project of Masaryk University no. MUNI/A/0749/2012.

\section{References}

Antoušková, M. (2008). Cestovni ruch jako faktor rozvoje regionu (Doctoral dissertation) (Tourism as the factor of region development). Praha: Česká zemědělská univerzita v Praze.

Balaguer, J., \& Cantavella-Jordá, M. (2002). Tourism as a long-run economic growth factor: the Spanish case. Applied Economics, 34(7), 877-884.

Becker, CH., Hopfinger, H., \& Steinecke, A. (2007). Geographie der Freizeit und des Tourismus: Bilanz und Ausblick. Mnichov: Oldenbourg.

Blair, J. P. (1995). Local Economic Development: Analysis and Practice. London: Sage Publications.

Blažek, J., \& Uhlíř, D. (2002). Teorie regionálního rozvoje (Regional development theory). Praha: Karolinum.

Brenner, L., \& Aguilar, A. G. (2002). Luxury Tourism and Regional Economic Development in Mexico. The Professional Geographer, 54(4), 500-520.

Britton, S. G. (1982). The political economy of tourism in the third world. Annals of Tourism Research. 9(3), 331-358. DOI: 10.1016/0160-7383(82)90018-4

Butler, R. W. (1980). The concept of a tourist area cycle of evolution: Implications for management of resources. The Canadian Geographer/Le Géographe canadien. 24(1), 5-12.

Capello, R., \& Nijkamp, P. (2009). Handbook of Regional Growth and Development Theories. Cheltenham: Edward Elgar Publishing Limited.

Cooper, CH., Fletcher, J., Gilbert, D., Fyall, A., \& Wanhill, S. (2008). Tourism: Principles and Practi$c e$. Harlow: Pearson Education Limited.

Desai, V., \& Potter, R. B. (2002). The companion to development studies. New York: Oxford University Press.

Dwyer, L., \& Forsyth, P. (2006). International Handbook on the Economics of Tourism. Cheltenham: Edward Elgar Publishing Limited.

Eadington, W. R. (1992). Tourism alternatives: potentials and problems in the development of tourism. Philadelphia, PA: University of Pennsylvania Press. 
Elliott, J. (1997). Tourism: politics and public sector management. New York: Routledge.

Fayissa, B., Nsiah, C., \& Tadasse, B. (2008). Impact of tourism on economic growth and development in Africa. Tourism Economics, 14(4), 807-818. DOI: 10.5367/000000008786440229

Giaoutzi, M., \& Nijkamp, P. (2006). Tourism and regional development: new pathways. Burlington, VT: Ashgate.

Goeldner, C. R., \& Ritchie, J. R. B. (2006). Tourism: Principles, Practices, Philosophies. Hoboken: John Wiley \& Sons, Inc.

Goulet, D. (1989). Participation in Development: New Avenues. World Development, 17(2), 165-178. DOI: 10.1016/0305-750X(89)90242-8

Hall, C. M., \& Jenkins, J. M. (1995). Tourism and public policy: politics and public sector management. London: Thomson.

Hall, C. M., \& Page, S. J. (2006). The Geography of Tourism and Recreation: Environment, place and space. Abingdon: Routledge.

Hall, C. M. (2008). Tourism planning: policies, processes and relationships. New York: Pearson/Prentice Hall.

Hall, C. M., \& Lew, A. A. (2009). Understanding and Managing Tourism Impacts: An integrated approach. Abingdon: Routledge.

Holman, R. (2005). Dějiny ekonomického myšleni (History of economic thougth). Praha: C. H. Beck.

Holman, R. (2011). Ekonomie (Economics). Praha: C. H. Beck.

Christaller, W. (1963). Some Considerations of Tourism Location in Europe. Paper of the Regional Science Association, 12, 95-105.

Inskeep, E. (1994). National and regional tourism planning: methodologies and case studies. New York: Routledge.

Keller, P., \& Bieger, T. (2007). Productivity in tourism: Fundamentals and Concepts for Achieving Growth and Competitiveness. Berlin: Erich Schmidt Verlag.

Lordkipanidze, M., Brezet, H., \& Backman, M. (2004). The entrepreneurship factor in sustainable tourism development. Journal of Cleaner Production, 13(8), 787-798. DOI: 10.1016/j.jclepro.2004.02.043

Loukissas, P. J. (1982). Tourism's regional development impacts. Annals of Tourism Research, 9(4), 523-541. DOI: 10.1016/0160-7383(82)90071-8

Malecki, E. J. (1997). Entrepreneurs, networks, and economic development: a review of recent research. Advances in Entrepreneurship, Firm Emergence and Growth, 3, 57-118.

Moheb, A. G. (1976). Tourism and Economic Growth: An Empirical Study. Economic Development and Cultural Change, 24(3), 527-538. DOI: 10.1086/450895

Mowforth, M., \& Munt, I. (2009). Tourism and sustainability: development, globalisation and new tourism in the Third World. New York: Routledge.

Murphy, P. E., \& Murphy, A. E. (2004). Strategic management for tourism communities: bridging the gaps. Buffalo: Channel View Publications.

Nordin, S. (2003). Tourism Clustering E Innovation - - Paths to Economic Growth E Development. Utredningsserien / ETOUR - European Tourism Research Institute.

Page, S., \& Connell, J. (2009). Tourism: a modern synthesis. Andover: South-Western Cengage Learning. Page, S. (2007). Tourism management: managing for change. Amsterdam: Elsevier.

Repík, O. (2013). Vývoj systému podpory cestovního ruchu ze strukturálních fondů v České republice (Development of tourism subsidy system from structural fonds in the Czech Republic). In A. Holešinská (Ed.), 4th International Colloquium on Tourism. Preceedings. Pavlov, 12 - 13 September 2013 [CD-ROM] (pp 113-126). Brno: Masaryk University. 
Ryan, C. (2003). Recreational tourism: demand and impacts. Buffalo: Channel View Publications. Samuelson, P. A., \& Nordhaus, W. D. (2007). Ekonomie. Praha: Svoboda.

Seckelmann, A. (2002). Domestic tourism - a chance for regional development in Turkey?. Tourism Management, 23(1), 85-92. DOI: 10.1016/S0261-5177(01)00066-8

Sharma, K. K. (2004). Tourism and regional development. New Delhi: Sarup \& Sons.

Sharpley, R., \& Telfer, D. J. (2004). Tourism and development: Concepts and Issues. Clevelond: Channel View Publications.

Sharpley, R., \& Telfer, D. J. (2015). Tourism and development: concepts and issues. Bristol: Channel View Publications.

Shaw, G., Williams, A. M., \& Cooper, C. (1990). Tourism, economic development and the role of entrepreneurial activity. Progress in tourism, recreation and hospitality management, 2(1), 67-81.

Shaw, G., \& Williams, A. M. (2002). Critical issues in tourism: a geographical perspective. Malden, Mass.: Blackwell Publishers.

Skokan, K. (2004). Konkurenceschopnost, inovace a klastry v regionálním rozvoji (Competitiveness, innovation and clusters in the regional development). Ostrava: Repronis.

Stabler, M. J., Papatheodorou, A., \& Sinclair, M. T. (2010). The Economics of Tourism. Abingdon: Routledge.

Theobald, W., F. (1998). Global tourism. Boston: Butterworth-Heinemann.

Tluchoř, J. (2012). Vliv cestovního ruchu na regionálni rozvoj (Doctoral dissertation)(The influence of tourism on the development of a region and businesses in that region). Plzeň: Západočeská univerzita v Plzni.

Tosun, C., Timothy, D., J., \& Özturk, Y. (2003). Tourism Growth, National Development and Regional Inequality in Turkey. Journal of Sustainable Tourism, 11(2-3), 133-161. DOI: $10.1080 / 09669580308667200$

Tribe, J. (2012). The Economics of Recreation, Leisure and Tourism. Abingdon: Routledge.

Veal, A. J. (2002). Leisure and tourism policy and planning: politics and public sector management. New York, NY: CABI Publishing.

Wahab, S., \& Pigram, J. (1997). Tourism, development and growth: the challenge of sustainability. New York: Routledge.

Wall, G., \& Mathieson, A. (2006). Tourism: change, impacts, and opportunities. New York: Pearson Prentice Hall. 